\title{
THE SHAKY HIGH MORAL GROUND OF POSTMODERNIST "ETHICS"
}

\section{Gray, T Lovat}

\section{INTRODUCTION}

Hölscher's (2005) question, "Does postmodernism have a moral, ethical and values base?" appears as something of a paradox. But, as she rightly recognises, she is not the first to ask the question. In posing this question, Hölscher is merely following a long line of scholars, including Bauman, whose Postmodern Ethics (1993) form the theoretical backdrop to her discussion, and Foucault, whose ideas have been more influential than Bauman's on social work thinking (Chambon, Irving \& Epstein, 1999; Hugman, 2003, 2005). In the social sciences Bauman (1995), Benhabib (1992), Foucault (2000) and Young (1990) have grappled with the implications of postmodernism for ethics and morality. In social work Atherton and Bollard (2003), Gray (1995), Hugman (2003, 2005), Parton (1994) and Walker (2001), among others, have critically examined the ethical implications of the so-called "postmodern turn" in social work. In this paper the authors draw on the work of Berman (2000) in trying to unravel the high moral ground of postmodernism; engage in a re-evaluation of the impact of key figures in modern Western philosophy such as Wittgenstein and, especially, Habermas; and consider the implications of their work for social work.

\section{THE DILEMMA OF POSTMODERN ETHICS}

Hölscher (2005) reviews current debates on the role and function of ethical codes and standard setting in social work in postmodern conditions. She appeals for a "...discursive and nonessentialist Code of Ethics" (2005:237). In postmodern terms ethical judgments and processes remain open-ended, relational and context-specific. There can be no universal transcendental values such as human rights and social justice which apply to all people everywhere. Thus there can be no talk about judgments regarding universal values, such as respect for persons, human rights and social justice; no application of such values or ethical precepts in local contexts, where completely different cultural rules and moralities might apply, and where there might not even be such terms in local languages. In short, there can be no universally agreed-upon norms or codes; rather, each norm or code needs to be discursively constructed in particular situations in a process which can never be complete. In this respect it makes no sense to talk about moral certainty, and so postmodernity is seen as contributing to the loss of the "...ability of modern institutions to ensure the moral conduct of individuals" (Hölscher, 2005:239).

Ethics as moral philosophy makes no pretence to prescribe or enforce standards of moral conduct, but rather highlights the complexity of moral matters and the need for a deep understanding of morality so that individuals might choose or commit themselves to behave morally (Gray, 1993, 1995, 1996). Philosophically, the limitations of ethics have been well documented (Williams, 1985). The "postmodern turn" in ethics comes from social theory or the transforming of ethics into a social science. This turn became evident in the 1960s, when utilitarianism established its dominance as the most acceptable ethical method by which the complex issues of modern pluralist societies could be addressed (Lovat, 2003, 2004). It was an era that saw, in extreme instances, ethical decisions being made by committees using checklists and computing scores. The decision which scored highest was the decision enacted, regardless of any given sense of right and wrong according to the traditional view. Where decisions of this sort determined matters of life and death, as in the hospital ethics committee, for instance, the law of the land would often fortify this utilitarian approach to right and wrong by deeming the decision of such a committee, using such a 
method, to be the most powerful defence should a matter come to court. Especially when constituted by the requisite collection of stakeholder representatives charged by the institution with the task of determining ethical protocol, in the way in which Hölscher (2005) writes, the power of such a committee to re-write the rights and wrongs of the past has been determinative in many instances.

\section{ETHICS AS A SCIENCE}

True to its social scientific base, the method of attaining agreement is not one of referring to traditional sources, no matter how revered, but of rational investigation, logical deliberation and democratic resolution. With the right software on hand, the results of such a process could be fed into a computer and the final decision produced electronically (Reamer's Ethics Audit, 2001). Following hard on the heels of scientific scepticism and utilitarianism and laying the path for its emergence, came postmodernism which all but evaporated any hope that we might find grounds for some form of moral certainty or universalist ethics. Mounted initially as a corrective to the dominance of science, it spread its wave of uncertainty to all systems of thought, erecting in its stead its own particularly dogmatic propositions. So timid did many become about taking a strong stand on anything, lest one be accused of fundamentalism or breaching political correctness, that the hard issues of living in a complex, late modern, multicultural risk society have often not been confronted.

This is vividly brought home by Berman (2000) with reference to the assault of the New York Times journalist, Richard Bernstein, on the ideology of multiculturalism and "the new political correctness movement", which he describes as a "Dictatorship of Virtue" (2000:218). What began with the civil rights movement in the USA and with Martin Luther King Junior, namely a struggle for black rights or rather equal rights for all, ended up as racism and so-called multiculturalism. It is an example used by Bernstein (1995) (and Berman) to show how the original movement "...slipped from its moorings and turned into a new petrified opinion of the sort it was supposed to transcend" (Berman, 2000:219). This "new ism" is a "messianic program" which really is "monoculturalism" for "it does not take kindly to true difference" and, in many institutions (social work, politics, academia and other organs of government included):

"(it) ... has generated a kind of thought police who can easily frighten those who are scared of being labelled 'racist' or 'sexist'. Its alleged diversity is thus a fraud, because it imagines a world of enforced identical opinions. It denigrates notions of objectivity and achievement and celebrates the postmodern slogan that everything is socially constructed. White European males are now seen as the 'bad guys,' often required (if they wish to hold onto their jobs) to attend insensitive 'sensitivity sessions' or 'diversity training' that tell(s) them how to think and feel, and in which opinions different from those of the trainers are not tolerated. 'Respect for difference,' which is obviously a very good idea, has slipped into a secularized religion that will be imposed on everybody, and group affiliation is made into an ultimate principle. 'Virtue' is big here ... the attitude one of rooting out sin. In many institutions across the United States, including those of higher education, the result has been to shut down the free exchange of ideas. And all of this in the name of freedom." (Berman, 2000:219)

Thus, says Berman (2000), thought proceeds in terms of slogans in this multicultural Brave New World, especially in so-called "alternative" institutions. The result is a Manichean type of world of oppressor and oppressed, with the proponents of postmodernism frequently adopting Michel Foucault's (1974) jargon of "dominant discourse", "marginalized other" or "hegemonic curriculum", resulting in a "terrifying loss" in which we are "unwilling to defend complicated 
truths" (1974:219 italics added). For Bernstein, multiculturalism “...is an ideology that is unaware of itself as an ideology" (Berman, 2000:219). Importantly, Berman (2000:220) seeks to use this as an example to show how:

"...paradigms move within the orbit of hierarchy, of power relations, and that is why the New Truth becomes the Old Story in fairly short order ... rebellion against one orthodoxy only leads to another orthodoxy ... [thus] ... It takes no bravery to be a multiculturalist ... [and] ... Grants are typically awarded if the writer promises a 'radical transformation of the dominant paradigm' ... [rather than] 'This work might lead to modest changes in our way of thinking',"

Elsewhere Berman reminds us that "ism" stands for "incredibly short memory" (2000:225) such that with re-conditioned thinking - in terms of the new paradigm - goes a new "politically correct" vocabulary and the "fetishizing" of ideas "turning them into total explanations ... this tendency has reached a kind of apogee", says Berman, "...in the frenzy of finding a "new paradigm,' a new consciousness that will celebrate myth and ritual, ecology and transpersonal psychology, and leave the dull ugly world of science, history, and patriarchal/industrial society behind in the dust" (2000:220). One might place it under the "machine to green" religious banner for "...mechanistic science, the ultimate evil, will now be replaced by an "emerging planetary culture,' the ultimate good" (Berman, 2000:221). This "holistic paradigm", when it "does get institutionalized":

"... will give rise to a learning atmosphere that is cultish, zealous, and dogmatic. We now have large groups of people running around who can think systematically but not analytically; who rave about the 'sacred,' but haven't a clue as to the nature of scientific research; who chatter on about the 'tyranny of experts' when they have no expertise themselves. Cultural relativism is passed off as sophistication, when it is little more than sophistry; 'diversity' becomes a slogan, repeated with a new hypnotic grunting; quantum mechanics is held up as a new philosophy, even though most of its proponents can't do a single freshman physics problem. In an apt bit of satire of this kind of self-deception, the (North) American psychologist S.I. Shapiro writes of the 'incredible beliefs' endemic to the field of transpersonal psychology, whose 'more advanced members,' ... 'would of course never harbour such astonishing assumptions.' These include: 'It's all in the mind'; 'Everything is perfect'; 'Modern physics confirms transpersonal psychology'; 'The planet is undergoing a transformation into consciousness'; and 'Transpersonal psychology will change the world'." (Berman, 2000:222-223)

Berman (2000:223) hopes that this addiction to paradigms will give rise to some "halfway houses" or "twelve-step programs" to help people break out of their addiction which, like drugs and alcohol, provides short-term ecstasy while "robbing them of their real life", not to mention that such "blind mythologizing", as in the transpersonal psychology example cited above, is politically disastrous. For Berman this "transpersonal tyranny", which "turns history into archetypical psychology and takes hermeneutics ... and postmodernism to be the new truth" is "scary" (Berman, 2000:233). He cites Hannah Arendt's comment that "...the presumption of any great, hidden purpose in history that is ineluctably working itself out and that must inevitably lead to some specified outcome (good or bad) 'is one of the most virulent and dangerous diseases of the modern age"'(Berman, 2000:224). Thus utopian thought or the belief that all conflict will be resolved and that Western civilization will finally come to rest is what Albert Camus referred to as "nostalgia for the absolute" (Berman, 2000:224). Citing Kant he says "...a revolution will never produce true reform in ways of thinking. Instead new prejudices, like the ones they replaced, will 
serve as a leash to control the great unthinking mass" (Berman, 2000:227). For Berman this aptly captures "the whole process of paradigm merry-go-round" (Berman, 2000:227).

The new paradigm story of postmodernism is a classic case of an ideology-driven dubious logic, as is the story that "feminism will replace patriarchy" and "ecology will replace control of nature", treating these ideas as if they were scientific fact or prophecy of sorts (Berman, 2000:227). What then is the solution to this treadmill, to this game without end? For Berman (2000:228), it is to experience life "as it presents itself" and "to really grasp the fact that 'there' is not necessarily going to be very different from 'here'." And:

"... to recognize that what we need is not a dramatic transformation of reality and culture, but simply the willingness to live in this culture and reality as we work on the intelligent repair of present problems, without the hype or bombast, and let the future take care of itself. For that future, when it arrives, will have its problems, and we shall have to deal with them". (Berman, 2000:229)

Thus, neither postmodernism nor systems theory - popular with the ecology movement - can save us, even though the latter might have better explanations for some types of human interaction than other social and behavioural science theories. Our "desire to make connections" is what Cornelius Castoraidis calls "the monster of unifying madness" (Berman, 2000:243). It is humorously displayed in the movie I (heart) Huckabees. The problem is that proponents of these theories are zealots who behave like religious fanatics, placing their pseudo-scientific theories in a transcendent garb such that useful insights are caught up in a "game of smoke and mirrors" (Berman, 2000:240). The same might be said of the theory of ethics which "finally tells us nothing at all", for "no theory of ethics (or set of communal rituals) is likely to make us behave decently" (Berman, 2000:240). What we need to recognise, as did Wittgenstein in his later years, is that "the solution to the problem of life ... is to be seen in the disappearance of the problem" (Berman, 2000:202), in the living of life in the here and now as life to be lived as it is in the world as I found it (Duffy, 1987).

While such approaches may have been suitable to their time, one would be inclined to think that that time has come and gone. Less than ever are complex multicultural, multi-valued and multifaith societies like those of South Africa, Australia, the USA, Canada and the UK able to determine agreed ethical action by scientific audit. With increasingly significant populations of Islamic, Buddhist, Hindu, conservative Christian and "New Age" followers, a new pluralism is invading the space once dominated by the secularism of social science. In this space the trusted and largely unquestioned methods of yesteryear appear aseptic and incapable of addressing satisfactorily the concerns of its inhabitants. Lovat (2003) suggests that, in this new pluralist society, hardcore utilitarianism and its ethical methods require modification and that this modification is apparent in the re-positioning occurring in recent bioethical research across a number of fields (Davis, 1996; Doukas \& Berg, 2001; Kalbian \& Shepherd, 2003; Macklin, 1995; Magnusson, 1996; Miller \& Brody, 2002; Robertson, 2001; Wendler \& Shah, 2003; Zoloth, 2002). The rest of this paper will be devoted to explaining this fundamental shift with reference to the insights of Wittgenstein and, especially, Habermas.

\section{WITTGENSTEIN AND RELATIVISM}

There are many concepts used in postmodernism emanating from Wittgenstein's philosophy, whom Berman (2000) describes as a "spiritual nomad" - the later Wittgenstein, anyway - and "one of the greatest thinkers of modern times" (Berman, 2000:192). Wittgenstein embodies what Deleuze calls "rhizomatic thinking" - though ironically Deleuze saw no value in Wittgenstein's philosophy - which Berman describes as "paradox" or "spiritual nomadism", the sense of not 
going anywhere precisely because it understands that, in the most fundamental sense, there is really nowhere to go. As the twelfth-century Zen master, Hakuin, said ".... without a destination, I am never lost" (Berman, 2000:192). In his later years Wittgenstein came to reject the grounding of mathematics in logic - the subject of his Tractacus, which he finished in 1915 but which only appeared in print in 1922, intriguingly minus its mystical material. Here he acknowledges that "certain (intuitive) experiences are ineffable". Hence his misunderstood concluding sentence: "Whereof one cannot speak, thereof one must remain silent" (Berman, 2000:194).

Monk's (1990) book on Wittgenstein from which Berman (2000) derives this intuitionist reading of his philosophy traces it to Brouwer's influence. While influenced by Russell in his early work, shortly after the publication of Tractacus he became aware of Brouwer's rejection of "the idea that mathematics needed to be grounded in logic" - the complete opposite to the rationalist school - or the notion that there was a "mind-independent mathematical reality about which mathematics can make discoveries ... mathematics is not a body of facts but a construction of the human mind" (Monk, in Berman, 2000:197). Thus says Berman, it is precisely this direction, which one might call "psychological" or even "anthropological", that is evident in Wittgenstein's later work. Berman sees Wittgenstein as expressing in Tractacus his view that "...it was only those things that lay beyond scientific scrutiny that were important in life" (Berman, 2000:199 italics added). It is in this context that one needs to view Wittgenstein's statement that "...the solution to the problem of life is to be seen in the disappearance of the problem" as scientifically or mathematically defined. The real issue is not whether there is a mind-independent reality or whether language obeys the rules of logic, but to understand those things which are beyond the purview of such questions, those things in relation to which such questions are meaningless. Thus Berman (2000:205) says that:

“... to live with any degree of reason at all - the transcendence of the Tractacus (or any similar vertical/rationalist outlook) is absolutely unavoidable. For without some degree of verticality or objectivity, the language games and the tribalism of various thought communities cannot even be discussed because one would not be able to get inside of them to discuss them. Hence Wittgenstein's remark ... less than a year before he died, (in 1951) that the "sense of the world must lie outside the world. In it there is no value, it must lie outside all happening and being-so."

\section{HABERMAS AND ETHICS AS TRANSCENDENT}

Berman wants to drive home the point that any assertion of truth is necessarily a transcendent activity and Habermas (1972) would seem to agree when he postulates "self-reflectivity" as the supreme form of knowing. This is a form of knowing which is beyond that which can be formed from empirical evidence and from human interaction. It is a knowing which comes ultimately from self-knowing in the way of the mystics of Judaism, Christianity and Islam (Lovat, 2006). For Habermas, this knowing builds on the knowing that comes from empirical evidence and, more importantly, on the knowing that comes from human communication. In this, Habermas is building partly on the edifice provided by the later Wittgenstein who insisted that "...every language-game is only possible if one trusts something" (in Berman, 2000:206), thus "every language game presupposes that the communicating partners in the game take numerous facts for granted" (Berman, 2000:206).

Karl-Otto Apel - a Habermasian ally - would later emphasise that "criticism presupposes a transcendental framework in order to have a critical discussion at all" for "all examination or discourse takes place within a system" (in Berman, 2000:206) and it is important to know which system you are in or are using when conducting your critical analysis (Habermas, 1994). If one 
has any reflective abilities, one would realise that to opt for a world of pure universals - as rationalists or scientists do - or one of pure local tribalism - as deconstructionists and postmodernists do - is not justified. We have to walk the tightrope between the local and the universal, to follow what Wittgenstein called his "grief" in having to "walk on air" (in Berman, 2000:207). Thus Berman (2000) concludes that on an individual level, the problem of these "two godheads" as Wittgenstein called them, “...disappears because we are living in a way that turns it into a non-problem" (Berman, 2000:207), into understanding that this is just the way things are. We might just have to accept Bauman's aporesis (in Hölscher, 2005), his term for "a contradiction that cannot be overcome and which therefore results in conflict that cannot be resolved, coupled with an inability to admit such contradiction indeed exists" and live with the truth that some problems are insoluble, that all civilizations are unstable, and that they all change in time. Perhaps it is enough to know that the "global economy" and "transnational corporate hegemony" cannot last forever, "no civilization does" (Berman, 2000:244; see also Fernández-Armesto, 2001). "To submerge the entire planet in a business culture is demeaning to human beings and inimical to life itself; and ... I am convinced that there is a life force that knows beyond a doubt that a life circumscribed by commercial values and video display terminals is no life at all" (Berman, 2000:244). Nevertheless, “...there is no salvation on this path, only questions, indications, possibilities" (Berman, 2000:245) and paradox.

In this context, it is worth noting that the epistemic concerns of Habermas $(1972,1974)$ with communicative and reflective knowing resemble both the Aristotelian (Aristotle, 1985) and Thomist (Aquinas, 1936) concerns with "practical judgment" and the Husserlian (Husserl, 1958) concern with slow pre-emptive judgment through prolonging openness to learning anew. Indeed, the connections between the Habermasian and Husserlian world views have been well explored, both by Habermas himself (Habermas, 1985) and by others (Outhwaite, 1994; Rasmussen, 1990). Within the context of these connections, Habermas deals with the limitations of Wittgenstein's version of linguistic analysis. While acknowledging the debt the philosophical world owes to Wittgenstein (1958, 1969), Habermas refers to a certain lack of reflectivity in the scheme, emanating essentially from its failure to address the hermeneutic dimension. This leads to an overly simple analysis of the language games which characterise cross-cultural study. Thus says Habermas (1988:137), “...reflective linguistic analysis accomplishes a communication between different language games. Wittgenstein does not analyse (this) adequately ... With this we arrive at the field of hermeneutics, which Wittgenstein did not enter".

For Habermas, knowing required a heavy hermeneutic dimension which ultimately could lead to the forms of self-knowing that underpin his notion of praxis (Habermas, 1972, 1974) and of intersubjective understanding that is at the heart of communicative competence (Habermas, 1984, 1987). For him, this owed much to Husserlian philosophy. Thus he says that "praxis philosophy renewed by phenomenology and anthropology ... has at its disposal the tools of the Husserlian analysis" (Habermas, 1985:317) and "communicative reason makes itself felt in the binding force of intersubjective understanding and reciprocal recognition" (Habermas, 1985:324).

In turn, there are more than accidental connections between Husserlian thought and Eisner's (1979) view that, epistemically, over-attentiveness to what can be contained by discourse can lead to what he refers to as "discursive reductionism", a secondary rather than primary form of knowing in which knowing is assumed to be a product of discourse, in the way of the later Wittgenstein. For Eisner, it is the most hopeless by-product of, first, a cognitively obsessed, then, empirically obsessed, series of generations that we cannot now see the obvious truth that knowing precedes as often as follows from, and is always a little more than, the words that contain it - just ask someone in love! Furthermore, for Eisner, it is this hopeless by-product that afflicts 
educational and social practices, so limiting all forms of educational and professional training, including their assessment practices, to what is easily known and most testable, not to mention most likely ethnocentric, contentious, and liable to prolong inequity, lack of access and unethical action (Lovat, 2001).

In this context Habermas's understanding of the distinction between morals, values and ethics is most enlightening. Briefly, as a follower of the Enlightenment tradition, Habermas is a critical theorist of late modernity. As suggested above, he proposes that there are three ways in which we come to know motivated by our cognitive human interests. Like Aristotle and Aquinas and the long line of Western philosophers that follow them, Habermas places reason at the centre of his philosophy as the means through which we discern truth. At the same time, he shows that we have and need different types of knowledge for different purposes. He speaks about empirical-analytical - or scientific - knowing, historical-hermeneutical knowing and emancipatory knowing, which he respectively places in three spheres, the objective, social and subjective. His distinction between values, ethics and morals as corresponding to these three spheres is particularly helpful in understanding the various ways in which we use these concepts in social work.

It makes sense that values are relative and culturally contingent facts. As Habermas reminds us, they are objective in the sense that they are part of the social fabric of all societies in the same way that normative assumptions are part of our every day discussions - Habermas calls them speech acts. They are part of the language we use to express our ideas and communicate with one another.

It also makes sense that ethics, including professional ethics, belong in the social realm, for they arise from a social process of discussion and debate wherein we agree on norms, both professional and social, regarding what we see as right or just for the society in which we live and the profession to which we are committed - in terms of the values we share that are common to our professional culture. Habermas calls this process whereby we reach agreement through rational discussion "communicative rationality". To use a concrete example, a code of ethics for social work is always the result of a dialogical process which ends - albeit temporarily - when agreement is reached. It then becomes a "norm" of practice that social work professionals should adhere to the agreed-upon code. Importantly, this implies that codes of ethics change over time as new influences in knowledge and technological development lead to cultural changes. People shape codes of ethics in relation to the society in which they are embedded and change them as societies change. Hence codes of ethics are social and political professional statements.

Most on the button was Habermas's placement of morals in the subjective realm, believing that our moral beliefs are deeply personal matters, for only we can know whether or not we are being true to our values. Truthfulness is to the subjective, moral realm as rightness is to the social, ethical realm, and Habermas places emphasis on knowing ourselves as the person doing the knowing, as the subject trying to discern the truth of what we come to know. What better description could there be of "reflective practice"? In keeping with the Thomistic philosophical tradition, Habermas grounds truth in the feeling of personal freedom we feel when we are thinking and acting with integrity such that the truth sets us free, anchors us and makes us sure that our behaviour is being guided by our personal moral ${ }^{1}$ beliefs and values. So this is the sense in which Habermas uses the term "emancipatory knowing". He follows the Kantian tradition in holding that if we can discern that something is morally good for humans, then it must apply to all human beings everywhere. This was Kant's (1964) categorical imperative. In this vein Habermas sees

\footnotetext{
${ }^{1}$ Moral is being used here in its broadest sense to encompass not only our beliefs about how individuals ought to be treated, but also the social and political conditions for them to lead full and satisfying lives (it echoes the Aristotelian notion of human flourishing).
} 
morals as universal only when we can argue rationally that values like justice, honesty, integrity, non-violence and so on are shared features of our social reality which make social life possible and thus are good for all people everywhere. This too was Warnock's (1971) and Strawson's (1974) argument about minimally agreed-upon values across cultures and contexts.

Habermas provides a contemporary understanding of values, ethics and morality which is totally consistent with our thinking on values in social work, where values are seen as culturally contingent, while still acknowledging some shared universals such that we can talk about a profession of social work to which we can commit ourselves. This does not mean that there are not many different types of social work, or social works, responding to local cultures and contexts, but that across these diverse cultures there are some values which we all share that are encompassed in our notions of respect for others and social justice. This is not to say that Habermas has all the answers, for there are gaps yet to be filled, not least the importance of emotion in our reasoning processes (Nussbaum, 2001).

Some who miss a practical-mystical element in Habermas's thinking see his communicative rationality as highly proceduralised (Lovat, 2003, 2004). It is true that Habermas wants to show that society must create conditions for free and open discussion and debate such that all opinions might be heard and entertained in our inter-subjective, communicative reasoning processes. This thinking seems entirely consistent with social work thinking and the idea that it is our job to make sure that everyone has a voice, including people who are marginalised and discriminated against. In short, social work is broadly about making democracy work through ensuring that there is a strong public realm, or what Habermas - following Husserl - calls a life-world and what we might call civil society, in which communicative rationality - rational discussion or dialogue in terms of which we try to reach agreement - can be exercised. Where would society be without such open spaces and processes in compiling ethical codes?

Habermas's ideas are extremely practical, because they describe elements of our everyday interactions with one another and our attempts to reach understanding through reasoned discussion, and they affirm our belief in the value of democracy and a strong civil society. Like Aristotle and Aquinas, he emphasises the importance of practical reasoning and builds his theory from his observations of our inter-subjective human relations. Thus, Aristotle's notion of phronesis, Aquinas's notion of synderesis and Habermas's notion of praxis all emphasise that our moral sense and moral character is built up over time through right reason being applied to right action. We cannot become moral without engaging in everyday life and we cannot reach the truth until we are able to act with integrity - following the virtues - conceived as good habits which build character and fortify us. Thus "right reason applied to action", Aquinas's cardinal intellectual virtue of prudence, includes moral considerations.

\section{APPLICATIONS TO SOCIAL WORK AND SOUTH AFRICA}

Finally, Berman's (2000) "paradox" has a governing motif in Rilke's injunction to "...live in the question and perhaps you will gradually, without noticing it, live along some distant day into the answer" (Berman, 2000:211). This is the tradition of the later Wittgenstein and Gilles Deleuze. The point is to realize that reality as is was the mystery you were seeking all along. It challenges our constant quest for solutions and reminds us that "depths are on the surface" (Wittgenstein, 1969). After all our searching, we find what we were looking for right there "at home" in our ordinary everyday lives. The truth is staring us right in the face, but we do not want to see it because we think we must dig for it, in complex empirical data and high-level social science theorising. Who is to say that the grand solution or salvation we seek might not prove to be just as 
oppressive as that which we seek to escape? The grass is never greener on the other side. Even non-apartheid South Africa is beset by racism (Hölscher, 2005).

What then can social work learn from this? It could learn to see its work "in terms of the immediate task at hand" (Berman, 2000:237); to work against social inequality in a way that does not construe people's experience in terms of power but rather rhizomatically - "teaching the soul to live its life" (Deleuze, in Berman, 2000:241) rather than trying to save it - and compassionately (Nussbaum, 2001) - realizing that everyone is merely trying to make the best of their lives with the deck they have been dealt. This does not mean that we cannot work toward racial, gender and economic equality, and a closer relationship with the environment and deal with diversity. We can explore the "...dialectical possibilities ... between horizontal and vertical aspects of life ... [and accept that] certain problems can never get solved, but only improved upon ... [and] there is some relief in knowing this" (Berman, 2000:238).

At heart South Africans know the bitter truths that need confronting and they have a sound record in truth and reconciliation of which they can be proud. But romantic notions of rainbow nations and multiculturalism or pluralism or racial diversity prevent people from confronting the hard issues, choosing rather to skirt around them with political correctness. This is not helping anyone. Codes of ethics in social work will not solve such moral and ethical problems, nor will standards of education and practice, as Husband (in Hölscher, 2005) rightly points out. The problems are structural and relational. They lie inter alia in poverty and under-development and racial and cultural difference - more especially in racial and cultural (mis)understanding and intolerance. No amount of moral theorising will wish these problems away and all that social workers can do is confront the problems they encounter each day, treat their clients and one another with respect, chip away at the bureaucracy, advocate for their clients' rights, engage with cultural and racial issues and name them for what they are, and work steadily through each small step to create a better albeit imperfect world. Codes of ethics can assist in this by focusing on micro-ethics and by providing guidance to social workers on ethical practice. They are limited but useful and necessary, given that social work wants to claim professional status and all that goes with this. Codes of ethics are part of the modern trappings of professionalism and the quest for universal values and moral certainty. Social work is a values-based profession and it is this that constitutes its universal identity. But codes of ethics cannot solve problems or recognise contradictions; only people can do this. At best they are tools we can use, among other things, to guide practice and they are helpful tools if we use them well.

\section{CONCLUSION}

The paper has taken up the challenge provided by Hölscher to re-evaluate the real impact of postmodernist ethics on relativising norms and standards to the point that moral judgment becomes impossible. It has gone beyond Hölscher's critique in exposing an enigma and insidiousness in postmodernist ethics in its high moral ground stance against anyone other than a postmodernist taking the high moral ground. This has the effect of clouding the moral arena and watering down the standards that often need to be applied to complex social situations, especially in troubled multicultural settings. The paper has unravelled some of the high moral ground of postmodernism by utilizing the work of Berman. Furthermore, it has engaged in re-evaluation of the impact of key figures such as Wittgenstein and especially Habermas who, even as an alleged neo-Marxist, proposed a groundbreaking ethical schema that fits well with the philosophical theological tradition of the West and could even be described as based in a notion of transcendence. 


\section{REFERENCES}

AQUINAS, T. 1936. Summa theologica (tr L. Shapcote). London: Burns \& Oates.

ARISTOTLE. 1985. Nicomachean ethics (tr T. Irwin). Indianapolis: Hackett.

ATHERTON, C.R. \& BOLLARD, K.A. 2003. Postmodernism: A dangerous illusion. International Social Work, 45(4):421-433.

BAUMAN, Z. 1993. Postmodern ethics. Oxford: Blackwell.

BAUMAN, Z. 1995. Life in fragments: Essays in postmodern morality. Oxford: Blackwell.

BENHABIB, S. 1992. Situating the self: Gender, community and postmodernism in contemporary ethics. Cambridge: Polity Press.

BERMAN, M. 2000. Wandering God: A study in nomadic spirituality. New York: State University of New York Press.

BERNSTEIN, R. 1995. Dictatorship of virtue. New York: Vintage Books.

CHAMBON, A., IRVING, A. \& EPSTEIN, L. (eds) 1999. Reading Foucault for social workers. New York: Columbia University Press.

DAVIS, D. 1996. The role of Dharma in the understanding of professional morality among Hindu physicians in India. Monash Bioethics Review, 15(4):29-36.

DOUKAS, D. \& BERG, J. 2001. The family covenant and genetic testing. American Journal of Bioethics, 1(3):2-10.

DUFFY, B. 1987. The world as I found it. New York: Ticknor and Fields.

EISNER, E. 1979. The educational imagination. New York: Macmillan.

FERNÁNDEZ-ARMESTO, F. 2001. Civilizations. London: Pan Books.

FOUCAULT, M. 1974. The archaeology of knowledge (tr A. Smith). London: Tavistock.

FOUCAULT, M. 2000. Ethics: Subjectivity and truth - the essential works of Foucault 19541984, Volume 1 (ed Paul Rabinow, tr Hurley, R. et al.). London: Penguin.

GRAY, M. 1993. The relationship between social work, ethics and politics. Durban: University of KwaZulu-Natal. (Unpublished PhD thesis)

GRAY, M. 1995. The ethical implications of current theoretical developments in social work. British Journal of Social Work, 25(1):55-70.

GRAY, M. 1996. Moral theory for social work. Social Work/Maatskaplike Werk, 32(4):289295.

HABERMAS, J. 1972. Knowledge and human interests (tr J. Shapiro). London: Heinemann.

HABERMAS, J. 1974. Theory and practice (tr J. Viertal). London: Heinemann.

HABERMAS, J. 1984. Theory of communicative action (vol 1). Boston: Beacon Press.

HABERMAS, J. 1985. The philosophical discourse of modernity. Cambridge, UK: Polity Press.

HABERMAS, J. 1987. Theory of communicative action (vol 2). Boston: Beacon Press.

HABERMAS, J. 1988. On the logic of the social sciences. Cambridge: Polity Press. 
HABERMAS, J. 1994. The past as future. Lincoln: University of Nebraska Press.

HÖLSCHER, D. 2005. A postmodern critique of the SACSSP's Draft Code of Ethics, Social Work/Maatskaplike Werk, 41(3):237-250.

HUGMAN, R. 2003. Professional values and ethics in social work: Reconsidering postmodernism? British Journal of Social Work, 33(8):1025-1041.

HUGMAN, R. 2005. New approaches in ethics for the caring professions: Taking account of change for caring professions. London: Palgrave Macmillan.

HUSSERL, E. 1958. The idea of phenomenology ( $\operatorname{tr}$ W. Alston \& G. Nakhnikian). The Hague: Nijhoff.

KALBIAN, A. \& SHEPHERD, L. 2003. Narrative portrayals of genes and human flourishing. American Journal of Bioethics, 3(4):15-22.

KANT. I. [1785] 1964. Groundwork of the metaphysic of morals (tr H.J. Paton). London: Routledge.

LOVAT, T. 2001. In defence of phenomenology. Religious Education, 96(4):564-571.

LOVAT, T. 2003. The contribution of proportionism to bioethical deliberation in a moderately post-scientific age. Theology @ McAuley, 3. Available: http://www.mcauley.acu.edu.au/theology/Issue3/index.html

LOVAT, T. 2004. Aristotelian ethics and Habermasian critical theory: A conjoined force for proportionism in ethical discourse and Roman Catholic moral theology. Australian E-Journal of Theology, 3. Available: http://dlibrary.acu.edu.au/research/theology/ejournal/aejt 3/Lovat.htm

LOVAT, T. 2006. Practical mysticism as authentic religiousness: A Bonhoeffer case study. Australian E-Journal of Theology, 6. Available:

http://dlibrary.acu.edu.au/research/theology/ejournal/aejt_6/lovat.htm

MACKLIN, R. 1995. Cloning without prior approval: A response to recent disclosures of noncompliance. Monash Bioethics Review, 14(2):63-66.

MAGNUSSON, R. 1996. Testing for HIV without specific consent: A short review. Monash Bioethics Review, 15(4):2-8.

MILLER, F. \& BRODY, H. 2002. What makes placebo-controlled trials unethical? American Journal of Bioethics, 2(2):3-9.

MONK, R. 1990. Ludwig Wittgenstein. New York: Free Press.

NUSSBAUM, M. 2001. Upheavals of thought: The intelligence of emotions. New York: Cambridge University press.

OUTHWAITE, W. 1994. Habermas: A critical introduction. Cambridge: Polity.

PARTON, N. 1994. "Problematics of government", (post)modernity and social work. British Journal of Social Work, 24(1):9-32.

RASMUSSEN, D. 1990. Reading Habermas. Oxford: Basil Blackwell.

REAMER, F.G. 2001. The social work ethics audit: A risk management tool. Washington, DC: NASW Press. 
ROBERTSON, J. 2001. Preconception gender selection. American Journal of Bioethics, 1(1):29.

STRAWSON, P. F. 1974. Freedom and resentment and other essays. London: Methuen Co. Ltd.

Walker, S. 2001. Tracing the contours of postmodernism. British Journal of Social Work, 31(1):29-39.

WARNOCK, G.J. 1971. The object of morality. London: Methuen \& Co.

WENDLER, D. \& SHAH, S. 2003. Should children decide whether they are enrolled in nonbeneficial research? American Journal of Bioethics, 3(4):1-8.

WILLIAMS, B. 1985. Ethics and the limits of philosophy. London: Fontana Press.

WITTGENSTEIN, L. 1958. Philosophical investigations. Oxford: Blackwell.

WITTGENSTEIN, L. 1969. On certainty. Oxford: Blackwell.

YOUNG, I.M. 1990. Justice and the politics of difference. Princeton: Princeton University Press.

ZOLOTH, L. 2002. Jordan's banks: A view from the first years of human embryonic stem cell research. American Journal of Bioethics, 2(1):3-11.

Prof Mel Gray, Professor of Social Work at the University of Newcastle, New South Wales, Australia and Prof Terry Lovat, Professor of Education at the University of Newcastle, New South Wales, Australia. 